\title{
Speciation by triparental hybridization in genus Sorbus (Rosaceae)
}

\author{
Csaba Németh ${ }^{1,4} \cdot$ Nóra Papp $^{2} \cdot$ Jana Nosková ${ }^{3}$ Mária Höhn ${ }^{4}$
}

Published online: 15 July 2020

(c) The Author(s) 2020

\begin{abstract}
Hybridization associated with polyploidization and apomixis is a frequent mechanism of speciation. Sorbus is a genus with ongoing hybridization resulting in a polyploid complex with different parental lineage. Triparens is the smallest hybridogenous subgenus of Sorbus so far known to comprise only two taxa, S. intermedia and S. $\times$ liljeforsii that combine the genomes of three taxa (S. aria agg., S. aucuparia and S. torminalis). To elucidate the origins of S. dacica, S. paxiana and S. tauricola, three new trigenomic candidates formerly believed to be of biparental origin with either $S$. aria agg. $\times S$. aucuparia or $S$. aria agg. $\times S$. torminalis lineage we combined data from HPLC and chloroplast DNA analysing additional 33 related taxa as well. We concluded that the 'torminalis-type' flavonoid profile and the 'aucuparia-type' plastid indicate the participation of both S. torminalis and S. aucuparia resulting in the formation of S. dacica, S. paxiana and S. tauricola. Sorbus aria agg. as the third ancestor and as a necessary link to meet genes of $S$. torminalis and $S$. aucuparia in one genome is obvious from morphological features (densely tomentose undersides of leaves). The tetraploid cytotypes and obligate pseudogamy of $S$. dacica and S. paxiana were determined by flow cytometry and are published here for the first time. The most probable evolutionary scenario for Triparens species is: 1 . a diploid sexual $S$. aucuparia as pollen acceptor hybridized with a tetraploid apomictic taxon from the $S$. aria agg. producing a triploid apomictic taxon with 'aucuparia-type' plastid inherited maternally; 2. during a second crossing event this subgenus Soraria hybrid as maternal progenitor hybridized with the sexual diploid $S$. torminalis (providing gene(s) of apigenin O-glucuronide synthesis) forming a tetraploid Triparens hybrid with 'aucupariatype' plastid and 'torminalis-type' flavonoids.
\end{abstract}

Keywords Triparental hybridization $\cdot$ Taxonomy $\cdot$ Flavonoids $\cdot$ Chloroplast inheritance $\cdot$ Multiple origin $\cdot$ Sorbus subg. Triparens $\cdot$ Pseudogamy $\cdot$ Polyploidy

Electronic supplementary material The online version of this article (https://doi.org/10.1007/s42977-020-00003-x) contains supplementary material, which is available to authorized users.

Csaba Németh

nemetcsaba@gmail.com

1 Present Address: GINOP Sustainable Ecosystems Group, MTA Centre for Ecological Research, Klebersberg Kuno út 3, Tihany 8237 , Hungary

2 Department of Applied Chemistry, Faculty of Food Science, Szent István University, Budapest, Hungary

3 Department of Botany, Faculty of Science, Charles University, Prague, Czech Republic

4 Department of Botany and Soroksár Botanical Garden, Faculty of Horticultural Science, Szent István University, Budapest, Hungary

\section{Introduction}

Interspecific hybridization and polyploidization are important drivers of plant evolution and speciation forming new combinations by integrating genetic material mostly of two parent species [56]. The overwhelming majority of the hybridogenous Sorbus species are also of bipatental origin usually with $S$. torminalis (L.) Crantz or $S$. aucuparia L., more rarely $S$. chamaemespilus (L.) Crantz as maternal parent and a member of $S$. aria agg. as the paternal parent $[1,11,17,30,45,46,52,57,58,65]$ forming the hybridogenous subgenera Tormaria Májovský \& Bernátová ( $S$. torminalis $\times S$. aria agg.), Soraria Májovský \& Bernátová ( $S$. aucuparia $\times$ S. aria agg.) and Chamaespilaria Májovský \& Bernátová (S. chamaemespilus $\times$ S. aria agg.). There is, however, sporadic evidence for triparental speciation in Sorbus. Altogether 11 taxa are known to be triple hybrids, 9 of them are ranked in subgenus Chamsoraria Májovský \& Bernátová 
(S. chamaemespilus $\times S$. aucuparia $\times S$. aria agg.) [3, 44], whereas currently $S$. intermedia (Ehrh.) Pers. and $S . \times$ liljeforsii $\mathrm{T}$. Rich are classified as representatives of subgenus Triparens M. Lepší \& T. C. G. Rich (S. aucuparia $\times S$. aria agg. $\times$ S. torminalis) [53-55].

Morphological traits, mainly of leaves and fruits, have long been used to classify hybridogenous Sorbus taxa (e.g. $[18,25,44,54])$. In the 1970 s and the subsequent decades thin layer chromatography (TLC) was used as a method for taxonomical evaluation of Sorbus. Certain flavone glycosides have long been known as reliable and characteristic taxonomic markers suitable for judging the involvement of putaive parent species in hybridogenous speciation. FlavoneC-glycoside vitexin occurs solely in the leaves of S. torminalis, S. chamaemespilus and their hybrids as well as in $S$. umbellata agg., whilst some flavone-O-glycosides (luteolin 7-O-rhamnosylglucoside, luteolin 7-O-diglucoside, luteolin 7-O-glucoside, luteolin 4'-O-glucoside, apigenin 7-glucoside) are exclusive components of $S$. torminalis and its derivatives [7-10, 26].

In the course of studying both herbarium and living material of European Sorbus, beside the known S. intermedia and $S . \times$ liljeforsii, its backcross to $S$. aucuparia, three further species, S. dacica Borbás, S. paxiana Jáv. and S. tauricola Zaik. ex Sennikov presumed formerly to be of biparental origin are hypothesized here to have evolved by triparental hybridization. All of them combine morphological features of the three supposed ancestors: (i) the densely tomentose abaxial leaf side of $S$. aria agg., (ii) the greenish-yellowish colour of leaf underside (iii) and the brownish tinge of their fruits during ripening seen in S. torminalis, (iv) the more or less separated lower leaflet pair at least in some leaves of the long sterile shoots that indicates genetic involvement of S. aucuparia.

Sorbus dacica, a stenoendemic species of Transylvania, Romania, was described from the Trascăului Mountains [4, 5]. It has usually been suggested to have evolved by biparental hybridization between $S$. aria agg. and $S$. aucuparia [4, 21, 24, 25, 61, 63], but Pax [48] suspecting a trigenomic parentage suggested it arose as $S$. mougeotii $\times S$. torminalis hybrid ( $S$. mougeotii Soy.-Will. \& Godr. is well known to have $S$. aria agg. $\times S$. aucuparia origin).

Sorbus paxiana is a local endemic of the Cerna Mountains, South-eastern region of Banat, Romania [22]. Opinions are divided about its putative origin. Pax [48] who first published its occurrence considered it to be a hybrid of S. graeca (Spach) Schauer (belonging to $S$. aria agg.) and $S$. torminalis. Jávorka $[21,22]$ assumed its triparental derivation indicating either the sympatric S. graeca, S. austriaca (Beck) Hedl. and S. torminalis or $S$. borbasii and $S$. torminalis as the parent species, of which $S$. austriaca and $S$. borbasii have been undoubtedly resulted from $S$. aria agg. $\times S$. aucuparia crossing. Later it was believed to have originated via a biparental cross event either between $S$. aria agg. and S. aucuparia [24] or S. aria agg. and S. torminalis [25, 61].

Sorbus tauricola is an indigenous species of the Crimean Peninsula recognized and published first by Popov in 1959. It has congruently been supposed to have biparental origin with $S$. aria agg. and $S$. torminalis as ancestors and is known to be a tetraploid taxon [51, 60, 61, 66, 68, 69].

The aims of this study were (1) to investigate evidence for triparental origin of $S$. dacica, $S$. paxiana and $S$. tauricola by means of biochemical and molecular methods and (2) based on flow cytometry to assess their ploidy level and reproduction mode, and (3) delineate putative scenarios of their formation.

In a recent taxonomic paper, the non-hybrid Sorbus subgenera were interpreted at generic level and for the five hybridogenous subgenera, new generic names were introduced [61]. An alternative recent taxonomic treatment includes Sorbus s.1. in Pyrus [12]. Since there is as yet no general taxonomic consensus we follow the widely used traditional delimitation and treat our species under Sorbus with the corresponding accepted subgeneric names [41, 55].

\section{Materials and methods}

\section{Plant material}

To embed our 3 new trigenomic candidates, $S$. dacica, $S$. paxiana and $S$. tauricola in a wider taxonomic context we analysed further 33 related taxa collected at 68 different sites across Europe (58 natural growth sites and 10 gardens or streets of 12 countries) and classified in different European Sorbus subgenera as well. Thus altogether 146 individuals of 36 taxa were involved in our study including the four 'basic' parents $S$. torminalis, $S$. chamaemespilus, $S$. aucuparia and S. aria s.str., as well as their hybridogenous derivatives. 109 individuals were involved in biochemical analyses, 61 individuals were studied molecularly and 35 individuals were examined using flow-cytometry (Table 1). Locality details and methods applied for the single individuals are listed in the Supplementary Table. Except for some taxa where fewer samples were available, we analysed biochemically three or more individuals per taxon, whilst two individuals per taxon were studied molecularly. To reveal their ploidy level and reproduction mode we analysed 21 individuals of $S$. dacica and 13 individuals of $S$. paxiana. To check its ploidy level and reproduction mode one individual of $S$. intermedia was also analysed by flow cytometry. Ploidy level and reproduction mode of $S$. tauricola were not examined in lack of available fresh leaf and fruit material. Voucher herbarium specimens were deposited in the private herbarium of the first author. 


\section{Biochemical studies}

To evaluate the possible role of $S$. torminalis in the evolution of S. dacica, S. paxiana and S. tauricola we conducted HPLC-ESI-qTOFMS analysis comparing their apigenin $\mathrm{O}$-glucuronide and vitexin content with the putative parents as well as numerous closely related taxa both morphologically undoubtedly having and apparently lacking $S$. torminalis among the ancestors.

Acetonitrile and methanol (Prolabo HiPerSolv, VWR International, Radnor, PA, USA) were super gradient grade. Formic acid ( $\sim 98 \%$ for mass spectrometry) was obtained from Fluka (Sigma-Aldrich, St.Luis, MO, USA). Crystalline reference substance of vitexin was purchased from SigmaAldrich (Budapest, Hungary). A Milli-Q ultrapure water system (Merck Millipore, Billerica, MA, USA) was used throughout the study.

\section{Sample preparation}

$100 \mathrm{mg}$ sample of pulverized Sorbus leaves was weighed into PP tubes, and $5 \mathrm{~mL} 60 \%$ aqueous $\mathrm{MeOH}$ containing $1 \%$ formic acid and $25 \mu \mathrm{L}$ of $1000 \mu \mathrm{g} \mathrm{mL}^{-1}$ daidzein surrogate standard was added to each tube. Samples were extracted for $40 \mathrm{~min}$ in an ultrasonic bath $\left(<35^{\circ} \mathrm{C}\right.$ at the end $)$. Extracts were centrifuged for $10 \mathrm{~min}$ at $8000 \mathrm{~g}$, and $2.5 \mathrm{~mL}$ supernatant was transferred to another PP tube and diluted to $10 \mathrm{~mL}$ with water. Finally, samples were filtered through a $0.22 \mu \mathrm{m}$ PTFE membrane before injecting to the HPLC.

\section{Chromatographic separation}

Chromatographic separation was carried out on a Phenomenex Kinetex C18, 4.6×150 mm, $2.6 \mu \mathrm{m}$ column (Phenomenex, Macclesfield, UK) using an Agilent 1200 series high performance liquid chromatography (HPLC) system (Waldbronn, Germany). For the chromatography, 0.5\% $(\mathrm{v} / \mathrm{v})$ formic acid in water (mobile phase A) and $0.5 \%(\mathrm{v} / \mathrm{v})$ formic acid in acetonitrile (mobile phase B) were used as solvents at a flow rate of $500 \mu \mathrm{l} / \mathrm{min}$. For the qualification of polyphenolic compounds gradient program started at $8 \%$ $\mathrm{B}$, and after 5 min of isocratic run, solvent B was increased linearly and reached $45 \%$ at $35 \mathrm{~min}$ and then $100 \%$ at $40 \mathrm{~min}$. Finally, 100\% B was kept constant for 5 min, followed by $15 \mathrm{~min}$ isocratic re-equilibration for initial conditions. For the quantification of apigenin derivatives gradient program started at $25 \% \mathrm{~B}$, and after $1 \mathrm{~min}$ of isocratic run, solvent $\mathrm{B}$ was increased linearly and reached $44 \%$ at $8 \mathrm{~min}$ and then $100 \%$ at $9 \mathrm{~min}$. Finally, 100\% B was kept constant for $2 \mathrm{~min}$, followed by $15 \mathrm{~min}$ isocratic re-equilibration for initial conditions.

\section{HPLC-ESI-qTOFMS analysis}

The HPLC system including a diode array detector (DAD) was coupled to an Agilent (Santa Clara, CA USA) 6530 quadrupole-time-of-flight mass spectrometer (q-TOFMS), which was equipped with a dual spray ESI source. The q-TOFMS was used with the following operation parameters: capillary voltage, $4000 \mathrm{~V}$; nebulizer pressure, $40 \mathrm{psig}$; drying gas flow rate, $13 \mathrm{~L} / \mathrm{min}$; gas temperature, $350{ }^{\circ} \mathrm{C}$; skimmer voltage, $65 \mathrm{~V}$. During the experiment fragmentor voltage was triggered automatically between 160 and $210 \mathrm{~V}$ in positive mode and 140 and $240 \mathrm{~V}$ in negative mode. The lower value represents mild conditions in order to minimize in-source fragmentation, while the higher one is to foster insource fragmentation. Full-scan mass spectra in the range of $\mathrm{m} / \mathrm{z}$ 50-1100 were recorded at $1.5 \mathrm{spectra} / \mathrm{s}$ scanning speed at all times during the chromatographic run. The instrument performed the internal mass calibration automatically, using an automated calibrant delivery system, which introduces the flow from the outlet of the chromatograph together with a low-flow (approximately $10 \mu \mathrm{L} / \mathrm{min}$ ) of a calibrating solution. The solution contains the internal reference of HP-921 [hexakis- $(1 \mathrm{H}, 1 \mathrm{H}, 3 \mathrm{H}$-tetrafluoro-pentoxy)-phosphazene] and purine. Protonated molecules of purine ([C5H5N4]+ at $\mathrm{m} / \mathrm{z}$ 121.0509) and HP-0921 ([C18H19O6N3P3F24]+ at $\mathrm{m} / \mathrm{z}$ 922.0098) were used as reference masses in positive ion mode, while deprotonated purine at $\mathrm{m} / \mathrm{z} 119.0363$ and the formic acid adduct of HP-0921 ([C19H19O8N3P3F24]- at $\mathrm{m} / \mathrm{z}$ 966.000725) were used for the same purpose in negative ion mode. The DAD was acquiring data in the range of 200-800 nm in 2-nm steps at $0.5 \mathrm{spectra} / \mathrm{s}$ acquisition speed. The quantification of vitexin (apigenin-8-C-glucoside) was carried out using reference standard and the standard addition calibration technique, the MS was used in TOF only mode and was set into the extended dynamic range instrument state. In absence of the other apigenin-glycoside (apigenin O-glucuronide) reference standard only the relative peak areas were compared. The relative areas were calculated as compound peak area/daidzein peak area.

\section{Molecular studies}

To test whether the 3 triparental candidates $S$. dacica, $S$. paxiana and $S$. tauricola possess 'aucuparia-type' plastid two cpSSR primer pairs were used comparing the fragment lengths with those of the putative parents as well as several closely related taxa both undoubtedly having and apparently lacking $S$. aucuparia among the ancestors.

DNA extractions were made from silica-dried leaves using a modified CTAB protocol [15, 67]. Amplification of two variable chloroplast DNA regions was carried out by using rpl16 pm1 and trnT-L pm1 primer pairs targeting rpl16 gene intron as well as intergenic spacer between 
trnT (UGU) exon and trnL (UAA) 5' exon following Chester et al. [11] (Table 2). The PCR mixture (total volume, $25 \mu \mathrm{L}$ ) contained $1 \mathrm{U}$ Taq DNA Polymerase (Thermo Scientific, Inc.), $2.5 \mu \mathrm{L} 10 \times$ reaction buffer (Thermo Scientific, Inc.), $0.2 \mathrm{mM}$ dNTP Mix (Thermo Scientific, Inc.), $2.5 \mu \mathrm{M}$ each primer and 20-80 ng genomic DNA. The polymerase chain reaction (PCR) was carried out in an Esco AerisTM Thermal Cycler (Esco Healthcare Pte, Singapore) using the following heating profile: $4 \mathrm{~min}$ at $94{ }^{\circ} \mathrm{C}$ (initial denaturating step) followed by 32 cycles of $0.5 \mathrm{~min}$ at $94^{\circ} \mathrm{C}$ (denaturating step), $0.5 \mathrm{~min}$ at $50^{\circ} \mathrm{C}, 1 \mathrm{~min}$ at $72{ }^{\circ} \mathrm{C}$ (extension step) with an additional 8 min at $72{ }^{\circ} \mathrm{C}$ (final extension). PCR products were separated on $1 \%$ agarose gels ( $1 \mathrm{~g}$ agarose dissolved in $100 \mathrm{~mL} 1 \times$ TBE solution). Gels were stained with GelRed (Biotium, Fremont, CA, USA) and visualized under UV light. PCR fragments checked with gel electrophoresis were analysed by using ABI 3100 (Applied Biosystems, Foster City, CA, USA) capillary gel electrophoresis system adding to ROX 500 an internal lane size standard (Applied Biosystems) to the mix ( $2 \mu \mathrm{L}$ PCR product, $0.5 \mu \mathrm{L}$ internal size standard, $10 \mu \mathrm{L}$ HiDi formaldehyde). For evaluation of chromatograms Peak Scanner v1.0 (Thermo Fisher Scientific, MA, Waltham, USA) software was applied.

\section{Flow cytometry}

\section{Estimation of somatic DNA ploidy level}

DNA ploidy level of 35 adult trees (13 individuals of $S$. paxiana, 21 individuals of $S$. dacica and 1 individual of $S$. intermedia) was assessed by flow cytometry with DAPI (4',6-diamidino-2-phenylindole) as a fluorescent stain. Bellis perennis $\mathrm{L}$. $(2 \mathrm{C}=3.38 \mathrm{pg}$; [59]) was used as an internal standard. Preparation of samples generally followed a twostep procedure described by Doležel et al. [14]. Since only dried herbarium material was available we have not analysed S. tauricola.

Approximately $0.5-1 \mathrm{~cm}$ long part of a petiole was chopped together with an appropriate volume of fresh leaf tissue of the internal standard in a Petri dish containing $0.5 \mathrm{~mL}$ Otto I buffer $(0.1 \mathrm{M}$ citric acid monohydrate, $0.5 \%$ Tween 20; [47]). The nuclear suspension was then filtered through a $42 \mu \mathrm{m}$ nylon mesh and the samples were incubated for $10 \mathrm{~min}$ at room temperature, a staining solution consisting of $1 \mathrm{~mL}$ of Otto II buffer $\left(0.4 \mathrm{M} \mathrm{Na}_{2} \mathrm{HPO}_{4} \cdot 12 \mathrm{H}_{2} \mathrm{O}\right.$; [47]) supplemented with DAPI (final concentration $4 \mu \mathrm{g}$ / $\mathrm{mL}$; Sigma, Steinheim, Germany) and 2-mercaptoethanol ( $2 \mu \mathrm{L} / \mathrm{mL}$; Fluka, Buchs, Germany) was added. After 5 min of incubation at room temperature, fluorescence concentration was measured on a CyFlow ML (Partec GmbH, Münster, Germany) equipped with a UV LED $365 \mathrm{~nm}$. Fluorescence concentration of 3000 particles was recorded and fluorescence histograms were further analysed using FloMax
2.0 software (Partec GmbH, Germany). Ploidy levels were deduced based on the previous karyological studies of the genus Sorbus [31, 32].

\section{Determination of reproduction modes}

The modes of reproduction were determined based on the flow cytometric seed screen [42]. 9 seeds of one mother for S. paxiana, 54 seeds of 5 mothers for $S$. dacica and 31 seeds of one mother for $S$. intermedia were analysed. Each seed was analysed separately and only the lateral part of the seed was cut and used for the analysis. The rest of the procedure generally copied the one used for the leaf analysis however some small modifications were made. Bellis perennis or Carex acutiformis (2 C $=0.82 \mathrm{pg}$; [38]) were used as internal standards; the genome sizes were always recalculated to $B$. perennis using the ratio 3.319 (B. perennis/C. acutiformis) based on several simultaneous measurements of these two standards in different days. The volume of $0.7 \mathrm{~mL}$ of the buffer Otto I was used. After the filtration of the sample, incubation time was prolonged up to $30 \mathrm{~min}$. Then $0.5 \mathrm{~mL}$ of the sample's supernatant was refiltered and immediately mixed with the staining solution and measured. Modes of reproduction were inferred based on DNA ploidy levels of embryo and endosperm following Talent and Dickinson [64].

\section{Results}

\section{Biochemical studies}

Apigenin O-glucuronide was found to be a characteristic flavonoid component occurring exclusively in the leaves of $S$. torminalis and its progenies. The highest concentrations of apigenin O-glucuronide was detected in S. torminalis, whilst its putative descendants (taxa grouped in subgenus Tormaria and subgenus Triparens) also contained it in different and considerably smaller amounts. Of the subgenus Tormaria species, S. gayeriana Kárp. had the highest concentration. As far as subgenus Triparens is concerned we measured the highest concentration in S. intermedia and the lowest one in S. paxiana (see Table 3 for details).

Of the European 'basal' Sorbus species examined, vitexin occurred exclusively in the leaves of $S$. torminalis and $S$. chamaemespilus and their descendants (each taxon of the biparental subgenus Tormaria and subgenus Chamaespilaria in addition to the trigenomic subgenus Triparens). $S$. aria s.str. and S. aucuparia both lacked vitexin. The highest concentration was measured in S. chamaemespilus and its hybrid, S. $\times$ ambigua (Decne.) Beck. Taxa belonging to subgenus Aria proved to be rather heterogenous concerning their vitexin content. We did not detect vitexin in the leaves 
of S. danubialis (Jáv.) Prodan, S. graeca agg. and S. ulmifolia Kárp., whereas all morphotypes of $S$. umbellata agg. as well as $S$. domugledica Kárp., S. pannonica Kárp. and $S$. vajdae Boros contained this compound, in the case of the last three taxa suggesting their possible $S$. umbellata origin.

Species of subgenus Tormaria contained vitexin in various amounts. S. semiincisa Borbás was found to contain the highest amount, whereas no vitexin was detected in $S$. pelsoensis. As we expected, subgenus Triparens taxa also contained vitexin. S. tauricola had vitexin in highest concentration, whereas it was present in S. paxiana and S. intermedia in smaller amount. In S. dacica it was found only in a trace amount (see Table 3 for details).

\section{Molecular studies}

Regarding the putative ancestors of subgenus Triparens species, fragment length of $S$. torminalis and each taxon
Table 1 Number of individuals of Sorbus taxa included in biochemical (HPLC), molecular (cpSSR) and flow cytometry (FCM) analyses

\begin{tabular}{|c|c|c|c|c|}
\hline $\begin{array}{l}\text { Subgenus/ } \\
\text { nothosubgenus }\end{array}$ & Taxon & $\begin{array}{l}\text { Biochemical studies } \\
\text { (HPLC) }\end{array}$ & $\begin{array}{l}\text { Molecu- } \\
\text { lar studies } \\
\text { (cpSSR) }\end{array}$ & $\begin{array}{l}\text { Flow } \\
\text { cytometry } \\
(\mathrm{FCM})\end{array}$ \\
\hline Torminaria & S. torminalis & 3 & 1 & \\
\hline $\begin{array}{l}\text { Chamaemespi- } \\
\text { lus }\end{array}$ & S. chamaemespilus & 3 & 1 & \\
\hline Sorbus & S. aucuparia & 3 & 1 & \\
\hline \multirow[t]{8}{*}{ Aria } & S. aria s.str. & 3 & 1 & \\
\hline & S. danubialis & 4 & 2 & \\
\hline & S. domugledica & 2 & 2 & \\
\hline & S. graeca agg. & 3 & 2 & \\
\hline & S. pannonica & 3 & 2 & \\
\hline & S. ulmifolia & 3 & 2 & \\
\hline & S. umbellata agg. & 13 & 1 & \\
\hline & S. vajdae & 3 & 2 & \\
\hline Chamaespilaria & S. $\times$ ambigua & 3 & 2 & \\
\hline \multirow[t]{12}{*}{ Soraria } & S. arranensis & 1 & 1 & \\
\hline & S. austriaca & 3 & 2 & \\
\hline & S. borbasii & 3 & 2 & \\
\hline & S. hazslinszkyana & 3 & 2 & \\
\hline & S. hohenesteri & 1 & 1 & \\
\hline & S. mougeotii & 2 & 2 & \\
\hline & S. pseudofennica & 1 & 1 & \\
\hline & S. pseudothuringiaca & 1 & 1 & \\
\hline & S. pulchra & 1 & 1 & \\
\hline & S. $\times$ thuringiaca & 3 & 2 & \\
\hline & S. transylvanica n.p. & 4 & 2 & \\
\hline & S. tuzsoniana & 3 & 2 & \\
\hline \multirow[t]{8}{*}{ Tormaria } & S. badensis & 2 & 2 & \\
\hline & S. bakonyensis & 3 & 2 & \\
\hline & S. balatonica & 2 & 2 & \\
\hline & S. bohemica & 2 & 2 & \\
\hline & S. gayeriana & 3 & 2 & \\
\hline & S. pelsoensis & 3 & 2 & \\
\hline & S. pseudolatifolia & 3 & 2 & \\
\hline & S. semiincisa & 4 & 2 & \\
\hline \multirow[t]{4}{*}{ Triparens } & S. dacica & 5 & 2 & 21 \\
\hline & S. intermedia & 3 & 1 & 1 \\
\hline & S. paxiana & 6 & 2 & 13 \\
\hline & S. tauricola & 1 & 2 & \\
\hline Total: & 36 & 109 & 61 & 35 \\
\hline
\end{tabular}


of subgenus Aria in rpl16 locus proved to be quite similar falling into the range of 142-146 bp, whilst trnT-L locus showed length of $272 \mathrm{bp}$. For $S$. aucuparia as the third presumed parent species we found $110 \mathrm{bp}$ and $238 \mathrm{bp}$ in rpl16 and trnT-L loci, respectively.

Each taxon of the hybridogenous subgenus Soraria had 109-111 bp in rpl16 locus, while in trnT-L the fragment length was uniformly $238 \mathrm{bp}$. All species of subgenus Triparens were found to have similarly $238 \mathrm{bp}$ in trnT-L locus. Except 112 bp in $S$. paxiana, all the remaining three species $S$. dacica, S. intermedia, $S$. tauricola were represented with 111 bp in rpl16 locus. Subgenus Tormaria represents 141-146 bp for rpl16 and 272-273 bp for trnT-L loci. $S$. chamaemespilus as well as its derivative $S . \times$ ambigua were characterised by $141 \mathrm{bp}$ as well as 271-272 bp for rpl16 and trnT-L loci, respectively (Table 3 ).

\section{Flow cytometry}

\section{Estimation of somatic DNA ploidy level}

The two potentially trihybrid species analysed for ploidy level, S. dacica and S. paxiana were tetraploid. Our measurement of one mother plant of $S$. intermedia confirmed it was tetraploid as well (see Table 4 for details).

\section{Determination of reproduction modes}

Seed analysis revealed only tetraploid embryos in all three studied taxa (S. dacica, S. paxiana and S. intermedia). The endosperm/embryo ratios indicate pseudogamous reproduction mode of all three species (see Table 5 for details). The pollen contribution to endosperm development was exclusively tetraploid in the case of $S$. intermedia $(4 \mathrm{x}$ embryo $+12 \mathrm{x}$ endosperm), mostly tetraploid $(4 \mathrm{x}+12 \mathrm{x})$ and rarely diploid $(4 \mathrm{x}+10 \mathrm{x})$ in $S$. dacica and $S$. paxiana. We therefore conclude that these species are either self-pollinated (by reduced or unreduced pollen) or received unreduced pollen from sympatric diploid species (possibly $S$. torminalis). One seed of $S$. intermedia and two seeds of $S$. dacica contained 16x endosperm, indicating three tetraploid polar nuclei involvement. Triploid pollen contribution which was observed in one $S$. paxiana seed was probably obtained from a co-occurring triploid species.

\section{Discussion}

\section{Taxonomic, chorological and nomenclatural notes}

Certain flavone-O-glycosides have been known for a long time as exclusive biochemical markers of $S$. torminalis and its hybrids with $S$. aria agg. (subgenus Tormaria). Several taxa belonging to subgenus Tormaria have been examined and all of them proved to contain apigenin O-glucuronide confirming the involvement of $S$. torminalis in their origin $[8,10,26]$. Our results are in agreement with these earlier observations and we also detected apigenin O-glucuronide in all subgenus Tormaria species studied, providing supporting evidence that $S$. torminalis was one of their parents. In accordance with these previous studies we did not detect apigenin O-glucuronide in any representatives of Aria, Sorbus, Chamaemespilus, Chamaespilaria and Soraria subgenera.

We also found apigenin O-glucuronide in S. intermedia, also detected by Challice and Kovanda [8], reflecting its close affinity to $S$. torminalis. S. tauricola formerly unambiguously classified in subgenus Tormaria $[51,60,61,66$, $68,69]$ was expected to have at least some content of apigenin O-glucuronide. This result supports its putative $S$. torminalis origin.

Despite some clear morphological features suggesting its feasible $S$. torminalis parentage (greenish-tomentose leaf underneath, orangey tinge of fruits), S. dacica has been widely considered to belong to subgenus Soraria $[4,6,18$, $21,24,25,61,63]$. The presence of apigenin O-glucuronide in the leaves of $S$. dacica supports the hypothesis that $S$. torminalis must be one of its parents. A $S$. torminalis lineage of $S$. paxiana has long been the subject of debate [21, 22, $24,25]$. Nevertheless, the apigenin O-glucuronide content of both species shows clearly the key role of $S$. torminalis as one progenitor in their formation.

Vitexin is a less specific chemotaxonomic marker in Sorbus occurring equally in subgenus Chamaespilaria ( $S$. chamaemespilus), subgenus Torminaria (S. torminalis), subgenus Aria (S. umbellata agg.) and in their hybrids [8-10, 26]; our results confirmed these published findings. We found that species of subgenus Tormaria contained vitexin in various amounts and in case of $S$. pelsoensis we did not detect any. Lack of vitexin in some subgenus Tormaria taxa was noticed by Challice and Kovanda [8, 10] and Kézdy [26] as well. This phenomenon can be explained with backcross processes towards the parent species during which the genes encoding production of flavone-C-glycoside might have been segregated from those encoding synthesis of flavone-O-glycosides. Contrary to the results of Challice and Kovanda [8] and Kézdy [26] we measured vitexin in each subgenus Tormaria taxon they also studied (S. bohemica Kovanada, S. bakonyensis (Jáv.) Kárp., S. semiincisa), even though in some cases only a trace amount. It might be interpreted with the higher resolution of HPLC-MS technology as opposed to PC or TLC methods they used. Concerning subgenus Triparens we also observed vitexin content in $S$. intermedia which is in concordance with earlier chemotaxonomic survey [8]. Vitexin detected in S. dacica, S. paxiana and $S$. tauricola also appears to confirm the involvement of $S$. torminalis as parental species in their formation since $S$. 
chamaemespilus does not occur sympatrically with either of them and $S$. umbellata agg. is found to co-exist only with $S$. paxiana ([21, 25], Supplementary table).

The molecular results are also in agreement with previous studies [11, 28, 29, 65]. Probably due to the comparatively distant relationship of the compound leaved $S$. aucuparia and the other, simple-leaved 'basic' European Sorbus taxa S. torminalis, S. chamaemespilus and $S$. aria agg. its plastid genome appears to be considerably distinct. Hence chloroplast markers are very useful for analysing the involvement of $S$. aucuparia in hybridization processes, of course only in case $S$. aucuparia is the pollen acceptor because of the maternal inheritance of chloroplast genomes. The conspicuously characteristic 'aucuparia-type' fragment length of the two examined chloroplast loci in all studied subgenus Soraria taxa provides evidence for the key role of $S$. aucuparia in the speciation. Nevertheless, since plastid DNA is known to be of maternal inheritance in angiosperms, our cpDNA analyses proved that $S$. aucuparia tends to take part in hybridization processes as pollen acceptor, receiving pollen from a member of the Aria group (subgenus Aria). This observation is in line with the results of other works which found that $S$. aria agg. is the most common pollen donor in hybridizations resulting in subgenus Soraria taxa [11, 17, 45]. The 'aucuparia-type' plastid of proved (S. intermedia) and putative (S. dacica, S. paxiana and S. tauricola) subgenus Triparens taxa also indicates their $S$. aucuparia origin and the participation of $S$. aucuparia in the hybridogenous speciation as maternal line.

Our flow cytometric results confirmed the long known tetraploidy and pseudogamy of S. intermedia [20, 33, 35-37, $45,49,50]$, on the other hand demonstrated tetraploid cytotype and pseudogamous apomixis in case of $S$. dacica and S. paxiana.

The 'aucuparia-type' chloroplast and the 'torminalistype' flavonoid content revealed that $S$. dacica, $S$. paxiana and $S$. tauricola must have genetic material inheriting both from $S$. aucuparia and $S$. torminalis and must have evolved by trigenomic hybridization. One member of $S$. aria agg. as the third parent is obvious from morphological features such as dense hairiness on the underside of the leaves. Furthermore direct hybrids between $S$. aucuparia and $S$. torminalis have never been observed. Consequently S. dacica, S. paxiana and $S$. tauricola should be placed in the triparental subgenus Triparens. With this reclassification the known number of taxa of subgenus Triparens increased to 5 (Fig. 1) and the distribution includes along with the Scandinavian-Baltic area $(S$. intermedia and $S$. $\times$ liljeforsii) also the Transylvanian (S. dacica) and Banatian (S. paxiana) regions in Romania, as well as the Crimean Peninsula ( $S$. tauricola).

Based on the recently introduced nomenclatural approach by Sennikov and Kurtto [61] and Sennikov [62], all the three-way hybrid taxa between $S$. aria agg., S. aucuparia 
Table 3 Results of biochemical and molecular studies showing the characteristic apigenin O-glucuronide content of Sorbus torminalis and its hybrids as well as the unique plastid type of Sorbus aucuparia and its derivatives

\begin{tabular}{|c|c|c|c|c|c|c|c|c|c|}
\hline $\begin{array}{l}\text { Subgenus/ } \\
\text { nothosubge- } \\
\text { nus }\end{array}$ & Taxon & $\begin{array}{l}\text { Range of } \\
\text { vitexin } \\
\text { content in } \\
\text { dried leaves } \\
(\mathrm{mg} / \mathrm{g})\end{array}$ & $\begin{array}{l}\text { Average } \\
\text { content of } \\
\text { vitexin in } \\
\text { dried leaves } \\
(\mathrm{mg} / \mathrm{g})\end{array}$ & $\begin{array}{l}\text { Range of } \\
\text { apigenin } \\
\text { O-glucuro- } \\
\text { nide content } \\
\text { in dried } \\
\text { leaves (mil- } \\
\text { lions cps) }\end{array}$ & $\begin{array}{l}\text { Average } \\
\text { content of } \\
\text { apigenin } \\
\text { O-glucuron- } \\
\text { ide in dried } \\
\text { leaves (mil- } \\
\text { lions cps) }\end{array}$ & $\begin{array}{l}\text { Type of } \\
\text { flavonoids }\end{array}$ & $\begin{array}{l}\text { rpl16 locus } \\
\text { (bp) }\end{array}$ & $\begin{array}{l}\operatorname{trnT}-\mathrm{L} \\
\text { locus } \\
\text { (bp) }\end{array}$ & $\begin{array}{l}\text { Type of chlo- } \\
\text { roplast }\end{array}$ \\
\hline Torminaria & S. torminalis & $0.265-0.512$ & 0.368 & $\begin{array}{r}17.667- \\
22.634\end{array}$ & 19.982 & $\begin{array}{r}\text { TORMI- } \\
\text { NALIS }\end{array}$ & 146 & 272 & \\
\hline $\begin{array}{l}\text { Chamae- } \\
\text { mespilus }\end{array}$ & $\begin{array}{l}\text { S. chamae- } \\
\text { mespilus }\end{array}$ & $2.675-5.935$ & 3.841 & nd & nd & & 141 & 271 & \\
\hline Sorbus & S. aucuparia & nd & nd & nd & nd & & 110 & 238 & AUCUPARIA \\
\hline \multirow[t]{8}{*}{ Aria } & S. aria s.str. & nd & nd & nd & nd & & 142 & 272 & \\
\hline & S. danubialis & nd & nd & nd & nd & & 142 & 272 & \\
\hline & $\begin{array}{l}\text { S. domugl- } \\
\text { edica }\end{array}$ & $0.054-0.083$ & 0.068 & nd & nd & & 142 & 272 & \\
\hline & $\begin{array}{l}\text { S. graeca } \\
\text { agg. }\end{array}$ & nd & nd & nd & nd & & 143 & 272 & \\
\hline & S. pannonica & $0.076-0.318$ & 0.189 & nd & nd & & 143 & 272 & \\
\hline & S. ulmifolia & nd & nd & nd & nd & & 142 & 272 & \\
\hline & $\begin{array}{l}\text { S. umbellata } \\
\text { agg. }\end{array}$ & $0.260-1.015$ & 0.579 & nd & nd & & 142 & 272 & \\
\hline & S. vajdae & $0.029-0.031$ & 0.030 & nd & nd & & 142 & 272 & \\
\hline $\begin{array}{l}\text { Chamaespi- } \\
\quad \text { laria }\end{array}$ & S. $\times$ ambigua & $0.654-2.583$ & 1.667 & nd & nd & & 141 & 272 & \\
\hline \multirow[t]{12}{*}{ Soraria } & S. arranensis & nd & nd & nd & nd & & 109 & 238 & AUCUPARIA \\
\hline & S. austriaca & nd & nd & nd & nd & & 109 & 238 & AUCUPARIA \\
\hline & S. borbasii & nd & nd & nd & nd & & 111 & 238 & AUCUPARIA \\
\hline & $\begin{array}{l}\text { S. hazslinsz- } \\
\text { kyana }\end{array}$ & nd & nd & nd & nd & & 109 & 238 & AUCUPARIA \\
\hline & $\begin{array}{l}\text { S. hohenes- } \\
\text { teri }\end{array}$ & nd & nd & nd & nd & & 108 & 238 & AUCUPARIA \\
\hline & S. mougeotii & nd & nd & nd & nd & & 109 & 238 & AUCUPARIA \\
\hline & $\begin{array}{l}\text { S. pseu- } \\
\quad \text { dofennica }\end{array}$ & nd & nd & nd & nd & & 109 & 238 & AUCUPARIA \\
\hline & $\begin{array}{l}\text { S. pseudo- } \\
\text { thuringi- } \\
\text { aca }\end{array}$ & nd & nd & nd & nd & & 109 & 238 & AUCUPARIA \\
\hline & S. pulchra & nd & nd & nd & nd & & 110 & 238 & AUCUPARIA \\
\hline & $\begin{array}{l}\text { S. } \times \text { thuringi- } \\
\text { aca }\end{array}$ & nd & nd & nd & nd & & 109 & 238 & AUCUPARIA \\
\hline & $\begin{array}{l}\text { S. transyl- } \\
\text { vanica n.p. }\end{array}$ & nd & nd & nd & nd & & 109 & 238 & AUCUPARIA \\
\hline & $\begin{array}{l}\text { S. tuzso- } \\
\text { niana }\end{array}$ & nd & nd & nd & nd & & 109 & 238 & AUCUPARIA \\
\hline \multirow[t]{5}{*}{ Tormaria } & S. badensis & $0.065-0.134$ & 0.099 & $1.677-2.377$ & 2.027 & $\begin{array}{r}\text { TORMI- } \\
\text { NALIS }\end{array}$ & 143 & 273 & \\
\hline & $\begin{array}{l}\text { S. bakony- } \\
\text { ensis }\end{array}$ & $0.025-0.065$ & 0.047 & $5.182-7.119$ & 5.951 & $\begin{array}{r}\text { TORMI- } \\
\text { NALIS }\end{array}$ & 144 & 273 & \\
\hline & S. balatonica & $0.076-0.110$ & 0.093 & $3.035-3.299$ & 3.167 & $\begin{array}{r}\text { TORMI- } \\
\text { NALIS }\end{array}$ & 144 & 273 & \\
\hline & S. bohemica & $0.095-0.143$ & 0.119 & $0.792-3.151$ & 1.972 & $\begin{array}{l}\text { TORMI- } \\
\text { NALIS }\end{array}$ & 144 & 273 & \\
\hline & S. gayeriana & $0.052-0.435$ & 0.199 & $8.131-9.553$ & 8.801 & $\begin{array}{r}\text { TORMI- } \\
\text { NALIS }\end{array}$ & 144 & 273 & \\
\hline
\end{tabular}


Table 3 (continued)

\begin{tabular}{|c|c|c|c|c|c|c|c|c|c|}
\hline $\begin{array}{l}\text { Subgenus/ } \\
\text { nothosubge- } \\
\text { nus }\end{array}$ & Taxon & $\begin{array}{l}\text { Range of } \\
\text { vitexin } \\
\text { content in } \\
\text { dried leaves } \\
(\mathrm{mg} / \mathrm{g})\end{array}$ & $\begin{array}{l}\text { Average } \\
\text { content of } \\
\text { vitexin in } \\
\text { dried leaves } \\
(\mathrm{mg} / \mathrm{g})\end{array}$ & $\begin{array}{l}\text { Range of } \\
\text { apigenin } \\
\text { O-glucuro- } \\
\text { nide content } \\
\text { in dried } \\
\text { leaves (mil- } \\
\text { lions cps) }\end{array}$ & $\begin{array}{l}\text { Average } \\
\text { content of } \\
\text { apigenin } \\
\text { O-glucuron- } \\
\text { ide in dried } \\
\text { leaves (mil- } \\
\text { lions cps) }\end{array}$ & $\begin{array}{l}\text { Type of } \\
\text { flavonoids }\end{array}$ & $\begin{array}{l}\text { rpl16 locus } \\
\text { (bp) }\end{array}$ & $\begin{array}{l}\text { trnT-L } \\
\text { locus } \\
\text { (bp) }\end{array}$ & $\begin{array}{l}\text { Type of chlo- } \\
\text { roplast }\end{array}$ \\
\hline \multirow{7}{*}{ Triparens } & S. pelsoensis & nd & nd & $1.820-7.658$ & 4.523 & $\begin{array}{r}\text { TORMI- } \\
\text { NALIS }\end{array}$ & 143 & 273 & \\
\hline & $\begin{array}{l}\text { S. pseudola- } \\
\text { tifolia }\end{array}$ & $0.029-0.084$ & 0.057 & $4.628-6.908$ & 5.427 & $\begin{array}{r}\text { TORMI- } \\
\text { NALIS }\end{array}$ & 146 & 272 & \\
\hline & S. semiincisa & $0.178-0.287$ & 0.235 & $3.845-6.841$ & 5.346 & $\begin{array}{r}\text { TORMI- } \\
\text { NALIS }\end{array}$ & 141 & 272 & \\
\hline & S. dacica & $0.010-0.055$ & 0.029 & $1.832-3.398$ & 2.530 & $\begin{array}{r}\text { TORMI- } \\
\text { NALIS }\end{array}$ & 111 & 238 & AUCUPARIA \\
\hline & $\begin{array}{l}\text { S. interme- } \\
\text { dia }\end{array}$ & $0.092-0.166$ & 0.130 & $3.439-5.337$ & 5.315 & $\begin{array}{r}\text { TORMI- } \\
\text { NALIS }\end{array}$ & 111 & 238 & AUCUPARIA \\
\hline & S. paxiana & $0.031-0.484$ & 0.206 & $0.102-2.430$ & 0.787 & $\begin{array}{r}\text { TORMI- } \\
\text { NALIS }\end{array}$ & 112 & 238 & AUCUPARIA \\
\hline & S. tauricola & 0.551 & 0.551 & 3.718 & 3.718 & $\begin{array}{r}\text { TORMI- } \\
\text { NALIS }\end{array}$ & 111 & 238 & AUCUPARIA \\
\hline
\end{tabular}

$n d$ not detected

Table 4 Results of flow cytometric analyses of $S$. dacica, S. paxiana and $S$. intermedia leaves; Bellis perennis was used as the internal standard

\begin{tabular}{llll}
\hline Taxon & S. intermedia & S. dacica & S. paxiana \\
\hline Number of individuals analysed & 1 & 21 & 13 \\
Observed sample/standard ratio & 0.78 & $0.75-0.79$ & $0.77-0.79$ \\
Average coefficient of variation of the sample & 2.81 & 2.64 & 2.79 \\
Average coefficient of variation of the standard & 1.77 & 2.87 & 2.35 \\
Estimated DNA ploidy level & $2 \mathrm{n} \sim 4 \mathrm{x}$ & $2 \mathrm{n} \sim 4 \mathrm{x}$ & $2 \mathrm{n} \sim 4 \mathrm{x}$ \\
\hline
\end{tabular}

Table 5 Flow cytometric seed screening results for S. dacica, S. paxiana and S. intermedia seeds; Bellis perennis (B) or Carex acutiformis (X) were used as internal standards

\begin{tabular}{|c|c|c|c|c|c|c|c|}
\hline Mother species & $\begin{array}{l}\text { Maternal } \\
\text { ploidy }\end{array}$ & Standard & $\begin{array}{l}\text { Number of } \\
\text { seeds }\end{array}$ & Embryo/standard ratio & $\begin{array}{l}\text { Endosperm/ } \\
\text { standard ratio }\end{array}$ & $\begin{array}{l}\text { Estimated ploidy } \\
\text { level of the embryo }\end{array}$ & $\begin{array}{l}\text { Estimated ploidy } \\
\text { level of the } \\
\text { endosperm }\end{array}$ \\
\hline \multirow[t]{5}{*}{ S. dacica } & \multirow[t]{5}{*}{4} & $\mathrm{~B}$ & 10 & $0.77-0.80$ & $1.94-2.06$ & 4 & 10 \\
\hline & & $X$ & 1 & 2.53 & 6.32 & 4 & 10 \\
\hline & & $\mathrm{B}$ & 15 & $0.77-0.79$ & $2.28-2.45$ & 4 & 12 \\
\hline & & $X$ & 26 & $2.50-2.72$ & $7.38-8.18$ & 4 & 12 \\
\hline & & B & 2 & $0.76-0.77$ & $3.02-3.04$ & 4 & 16 \\
\hline Total & & & 54 & & & & \\
\hline \multirow[t]{4}{*}{ S. paxiana } & \multirow[t]{4}{*}{4} & B & 2 & 0.79 & $1.99-2.02$ & 4 & 10 \\
\hline & & $\mathrm{B}$ & 1 & 0.8 & 2.19 & 4 & 11 \\
\hline & & B & 4 & $0.79-0.81$ & $2.34-2.42$ & 4 & 12 \\
\hline & & $X$ & 2 & $2.71-2.73$ & $8.01-8.05$ & 4 & 12 \\
\hline Total & & & 9 & & & & \\
\hline \multirow[t]{2}{*}{ S. intermedia } & \multirow[t]{2}{*}{4} & $X$ & 30 & $2.53-2.65$ & $7.71-8.07$ & 4 & 12 \\
\hline & & $X$ & 1 & 2.63 & 10.58 & 4 & 16 \\
\hline Total & & & 31 & & & & \\
\hline
\end{tabular}




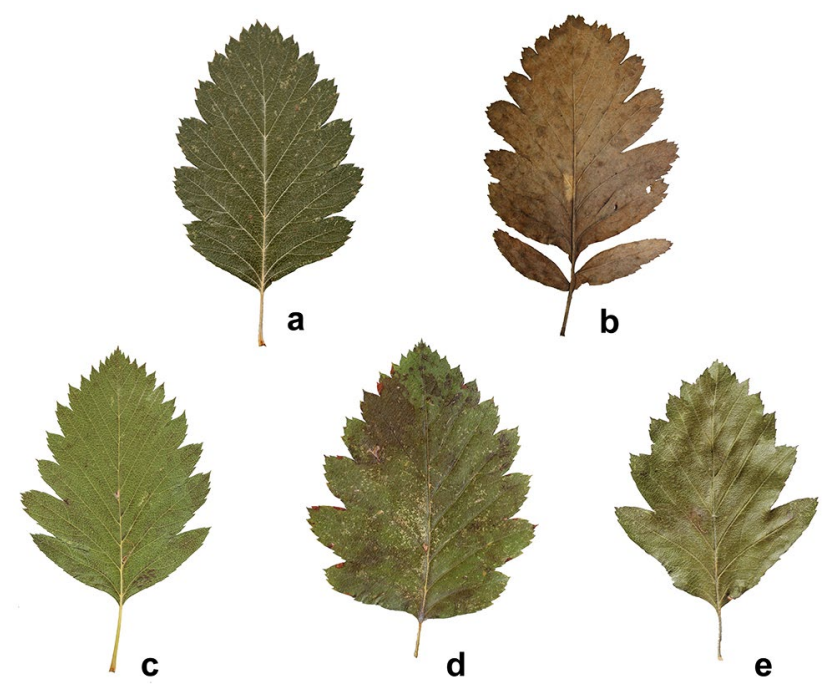

Fig. 1 Typical leaves of Sorbus subg. Triparens taxa. a Sorbus intermedia (from cultivation, Hungary), b Sorbus $\times$ liljeforsii (Garwnant Forest Centre, Wales), c Sorbus dacica (Torda Gorge, Romania), d Sorbus paxiana (Cerna Valley, Romania), e Sorbus tauricola (Crimean Mts, Crimean Peninsula) (scale bar: $1 \mathrm{~cm}$ )

and $S$. torminalis, namely $S$. dacica, S. paxiana, S. tauricola, $S$. intermedia and $S$. $\times$ liljeforsii would be accommodated in the genus Scandosorbus Sennikov (Scandosorbus replacing Borkhausenia Sennikov \& Kurtto for nomenclatural reasons; [62]). This nomenclatural approach is still under debate (see e.g. [34]), but if becomes accepted new combinations will be required for $S$. dacica, S. paxiana and $S$. tauricola.

\section{Putative scenarios of Triparens speciation}

Subgenus Triparens comprises apomictic Sorbus taxa that combine the genomes of $S$. aria agg., $S$. aucuparia and $S$. torminalis. They have evolved at least by two independent hybridization events. Since the chloroplast genome is maternally inherited in angiosperms including Sorbus, and each subgenus Triparens species shows 'aucuparia-type' plastid, $S$. aucuparia must be the ovule donor in at least one hybridization event.

The most probable evolutionary pathway is that as a first step, a diploid sexual $S$. aucuparia as pollen acceptor (contributing with a reduced haploid egg) hybridized with a tetraploid apomictic taxon from the $S$. aria agg. (contributing with a reduced diploid pollen) producing a triploid apomictic subgenus Soraria taxon with 'aucupariatype' plastid inherited maternally. Subsequently during a second crossing event this subgenus Soraria hybrid as maternal progenitor (providing an unreduced triploid egg and 'aucuparia-type' plastid) hybridized with the sexual diploid S. torminalis (providing a reduced haploid pollen containing gene(s) of apigenin $\mathrm{O}$-glucuronide and vitexin synthesis) leading to the formation of a tetraploid subgenus Triparens hybrid with 'aucuparia-type' plastid and apigenin O-glucuronide content (Fig. 2). Unreduced diploid pollen coming from diploid $S$. aria s.str. is unlikely, which is supported also by the results of Lepší et al. [33] who did not observe unreduced pollen in any studied individuals of diploid sexual $S$. aria s.str. at all. Further support for this scenario is that the diploid $S$. aria s.str. as a potential pollen donor is not native in the Baltic-Scandinavian region where $S$. intermedia has evolved [61]. The tetraploid S. rupicola (Syme) Hedl., the only subgenus Aria species occurring sympatrically is supposed to be as one of its parents [54]. S. aria s.str. has not been reported in the Crimean Peninsula either [61] and only tetraploid members of subgenus Aria have been found to co-exist with $S$. tauricola $[61,68,69]$. We have not detected any diploid $S$. aria s.str. growing together with $S$. dacica and $S$. paxiana either, but several tri- and tetraploid representatives of subgenus Aria were revealed by flow cytometric cytotype mapping (Nosková et al. unpublished data). This concept is supported also by the fact that at least one subgenus Soraria taxon always occur sympatrically with all known subgenus Triparens species ([21, 22, 25, 36, 68], Németh et al. unpublished data).

A second possible speciation pathway is that in the first hybridization event a reduced diploid male gamete of a tetraploid S. aria agg. fused with a haploid female gamete originating from the diploid $S$. torminalis. In biparental subgenus Tormaria Sorbus aria s.1. appears to be the most frequent pollen donor in hybridizations $[1,11,17,30,45,46,52,57$, $58,65]$, contrary to the very rare reverse direction of pollen flow $[45,46]$. As a second step the triploid subgenus Tormaria progeny as pollen donor with an unreduced triploid pollen fertilizes a haploid reduced female egg of $S$. aucuparia inheriting the chloroplast genes from the latter one and creating a tetraploid trigenomic subgenus Triparens species. Lepší et al. [33], however, did not find unreduced pollen among Sorbus s.l. they studied at all and even triploids produced reduced pollen. Hence this evolutionary route is much less likely. Moreover, there is no information on any subgenus Tormaria taxa as potential medial ancestor co-occurring with any subgenus Triparens species ([61], Németh pers. obs.), which also makes this scenario much less probable.

A third theoretic evolutionary pathway is that a member of $S$. aria agg. crossed with an interspecific hybrid of $S$. aucuparia and S. torminalis. However, this scenario is very unlikely because the hybridization between $S$. aucuparia and $S$. torminalis is hampered by their total incompatibility in both directions as reported earlier by Baksay [2] and in addition, no hybrid of these two species is known.

A final speculative evolutionary pathway is when a diploid amphimictic subgenus Soraria hybrid which produces 


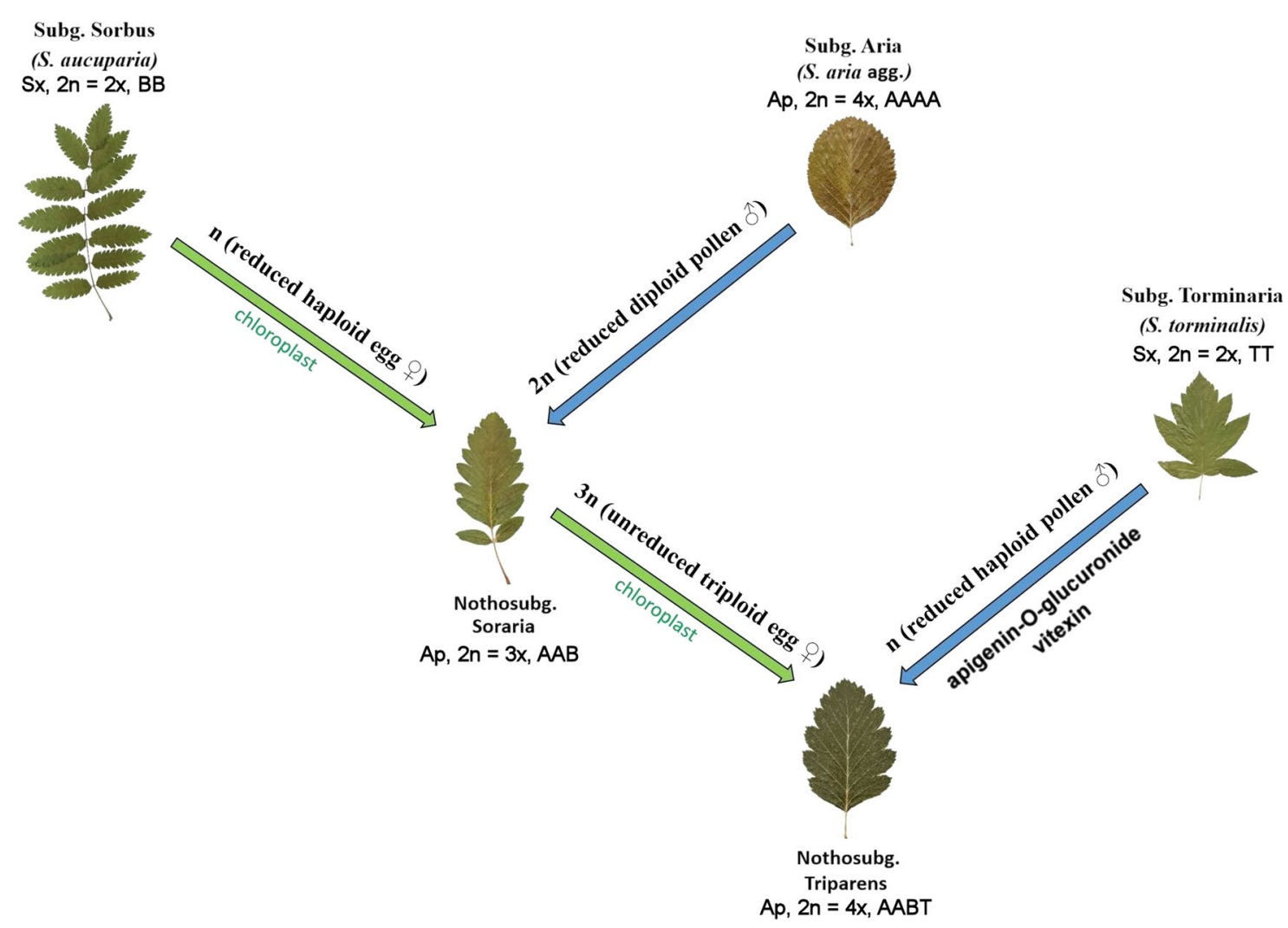

Fig. 2 The most probable hypothetical scenario of Sorbus subg. Triparens speciation via triploid subg. Soraria bridge, showing maternal inheritance of 'aucuparia-type' chloroplast from diploid sexual Sorbus aucuparia as well as inheritance of apigenin O-glucuronide and vitexin content from diploid sexual Sorbus torminalis in paternal line-

unreduced gamete crosses with an unreduced diploid gamete of an amphimictic subgenus Tormaria hybrid. Although this way of gamete fusion is not impossible but very improbable and hybrids with this kind of origin have hitherto not been reported.

\section{Conclusion for future biology}

Hybridization accompanied by polyploidisation is regarded as an important process in plant speciation. Allopolyploidy is considered to be a quite frequent phenomenon and plays a very important role in plant evolution usually with the involvement of two related species as parents. However, there is reasonably sporadic evidence for speciation by triparental hybridization in the plant world as a whole. For example, natural trigenomic taxa are known in Epilobium (Epilobium ciliatum $\times$ E. hirsutum $\times$ E. parviflorum, [27]), Potamogeton (Potamogeton perfoliatus $\times P$. gramineus $\times P$. lucens, [23]) and Cardamine (Cardamine rivularis $\times C$. amara $\times C$. pratensis, age. The supposed genome composition proposed by Liljefors [37] is indicated with capital letters (A: subgenus Aria genome, B: S. aucuparia genome, T: $S$. torminalis genome). Additional abbreviations: Sx: sexual, Ap: apomictic

[71]). Artificially produced triparental hybrids were published from the genera Melilotus [39], Rosa [19], Triticum [70], Allium [16] and Brassica [40]. They almost all belong to herbaceous plants. Although some published data are known about trihybrids in Salix and Populus (e.g. $[13,43])$, except for Sorbus s.l. there is no evidence for recent natural trigenomic hybridization and speciation among arboreal plants.

In Europe Sorbus is considered to be a very complicated group including plenty of hybridogenous polyploid apomictic species evolved by hybridization of the four obligately or facultatively sexual taxa Sorbus aria s.l., Sorbus chamaemespilus, Sorbus torminalis and Sorbus aucuparia. In most cases classification of these nothospecies based on morphological features appears to be quite reliable, occasionally the morphological approach alone can lead to misinterpretation concerning the exact taxonomic position. In this study biochemical and molecular methods are combined to reveal supposed triparental (S. aria agg., $S$. aucuparia, $S$. torminalis) origin of three stenoendemic, pseudogamous tetraploid Sorbus species formerly believed 
to be of biparental lineage (S. aria agg., S. aucuparia or $S$. aria agg., S. torminalis). The presence of both apigenin $\mathrm{O}$-glucuronide and vitexin as flavonoid markers in the leaves of Sorbus dacica, Sorbus paxiana and Sorbus tauricola suggests the involvement of Sorbus torminalis in their origin, whilst the characteristic type of their chloroplast clearly shows that Sorbus aucuparia also must have been among the parent species.

Our new results confirm the presence of triparental speciation mechanism within a genus which includes a number of taxa with restricted area and high degree of threat. Since hybridization is not only a mechanism of speciation but also a way of environmental adaptation, the recognition of triparental taxa and their studies in depth highly facilitate the understanding of plant responses to environmental changes.

Acknowledgements Open access funding provided by MTA Centre for Ecological Research (MTA ÖK). We are very grateful to our colleagues and friends Nóra Békefi, Zoltán Barina, Martin Lepší, Petr Lepší, Lenz Meierott, Gábor Mészáros, Norbert Meyer, Dániel Pifkó and László Máté Tálas for providing plant material and sharing their collections. Sincere thanks go to Peter Erzberger, Gergely Király, Andor Kovács, Gábor Mészáros, Dániel Pifkó, Balázs Pintér, Attila Rigó, András Schmotzer and László Máté Tálas for participatig in the field work. We would like to acknowledge Tamás Deák, Nikolett Kellner, Andor Kovács, Endre György Tóth for their kind help in labwork. We are also obliged to Sally Whyman, Welsh National Herbarium for loaning the herbarium specimen of $S . \times$ liljeforsii and to Myroslav Shevera for providing Russian literature of $S$. tauricola. Special thanks go to Tim Rich for comments on the manuscript and correcting the English.

Authors' contributions $\mathrm{CN}$ conceived of the presented idea, collected the vast majority of samples for all analyses, conducted molecular analyses, participated in biochemical analyses, wrote considerable part of the draft of the manuscript, prepared the majority of illustrations and took comments from the co-authors. NP was responsible for biochemical analyses, wrote the biochemical part of 'Materials and methods' section and contributed to the interpretation of the results. JN carried out flow-cytometric analyses, wrote the flow-cytometric part of 'Materials and methods' section, prepared flow-cytometric illustrations and contributed to the interpretation of the results. MH supervised the project.

Data accessibility The datasets supporting this article have been uploaded as part of the Supplementary Material.

\section{Compliance with ethical standards}

Conflict of interest We have no competing interests.

Open Access This article is licensed under a Creative Commons Attribution 4.0 International License, which permits use, sharing, adaptation, distribution and reproduction in any medium or format, as long as you give appropriate credit to the original author(s) and the source, provide a link to the Creative Commons licence, and indicate if changes were made. The images or other third party material in this article are included in the article's Creative Commons licence, unless indicated otherwise in a credit line to the material. If material is not included in the article's Creative Commons licence and your intended use is not permitted by statutory regulation or exceeds the permitted use, you will need to obtain permission directly from the copyright holder. To view a copy of this licence, visit http://creativecommons.org/licenses/by/4.0/.

\section{References}

1. Aas G, Maier J, Baltisberger M, Metzge S (1994) Morphology, isozyme variation, cytology and reproduction of hybrids between Sorbus aria (L.) Crantz and Sorbus torminalis (L.) Crantz. Bot Helv 104:195-214

2. Baksay L (1999) Sorbus-fajok embriológiaisejttani és származási vizsgálata. Kitaibelia 4(1):11-16

3. Bernátová D, Májovský J (2003) New endemic hybridogeneous species of the genus Sorbus in the Western Carpathians. Biologia (Bratislava) 58(4):781-790

4. Borbás V (1883) Floristikai közlemények. Mathematikai és Természettudományi Értesítő 1(3-4):81-88

5. Borbás V (1887) Correspondenz. Oesterreichische Botanische Zeitschrift 37(11):403-404. https://doi.org/10.1007/BF01648377

6. Buia A (1956) Sorbus L. In: Săvulescu T, Nyárády EI (eds) Flora Republicii Populare Romîne 4. Academia Republicii Populare Romîne, Bucureşti, pp 236-256

7. Challice JS (1981) Chemotaxonomic studies in the family Rosaceae and the evolutionary origins of the subfamily Maloideae. Preslia 53:289-304

8. Challice JS, Kovanda M (1978) Flavonoids as markers of taxonomic relationships in the genus Sorbus in Europe. Preslia 50:305-320

9. Challice J, Kovanda M (1985) A chemotaxonomix survey of Sorbus umbellata agg. Preslia 57:171-174

10. Challice JS, Kovanda M (1986) Flavonoids of Sorbus eximia. Preslia 58(2):165-167

11. Chester M, Cowan RS, Fay MF, Rich TCG (2007) Parentage of endemic Sorbus L. (Rosaceae) species in the British Isles-evidence from plastid DNA. Bot J Linn Soc 154:291-304

12. Christenhusz MJM, Fay MF, Byng JW (2018) The Global Flora. A practical flora to vascular plant speciesof the word. Special Edition. GLOVAP Nomenclature Part 1, vol 4, pp 1-155

13. Dickmann DI (2001) (2001) An overview of the genus Populus. In: Dickmann EI, Isebrands JG, Eckenwalder JE, Richardson J (eds) Poplar culture in North America. NRC Research Press, Ottawa, pp 1-42

14. Doležel J, Greilhuber J, Suda J (2007) Estimation of nuclear DNA content in plants using flow cytometry. Nat Protoc 2:2233-2244

15. Doyle JJ, Doyle JL (1987) A rapid DNA isolation procedure for small amounts of fresh leaf tissue. Phytochem Bull 19:11-15

16. Fredotović Ž, Šamanić I, Weiss-Schneeweiss H, Kamenjarin J, Jang TS, Puizina J (2014) Triparental origin of triploid onion, Allium $\times$ cornutum (Clementi ex Visiani, 1842), as evidenced by molecular, phylogenetic and cytogenetic analyses. BMC Plant Biol 14:1-12

17. Hajrudinović A, Frajman B, Schönswetter P, Silajdžić E, SiljakYakovlev S, Bogunić F (2015) Towards a better understanding of polyploid Sorbus (Rosaceae) from Bosnia and Herzegovina (Balkan Penisula), including description of a novel, tetraploid apomictic species. Bot J Linn Soc 178:670-685

18. Hedlund T (1901) Monographie der Gattung Sorbus. Kungliga Svenska Vetenskaps-Akademiens Handlingar, nov. ser 35:1-147

19. Iwata H, Kato T, Ohno S (2000) Triparental origin of Damask roses. Gene 259:53-59

20. Jankun A (1994) Embryological studies in Sorbus intermedia. Polish Bot Stud 8:69-74

21. Jávorka S (1915) Kisebb megjegyzések és újabb adatok III. Botanikai Közlemények 14(3-4):98-109 
22. Jávorka S (1927) A Sorbus torminalis (L.) CR. magyar keverékfajai. Magyar Bot Lapok 25:83-90

23. Kaplan Z, Fehrer J (2007) Molecular evidence for a natural primary triple hybrid in plants revealed from direct sequencing. Ann Bot (Oxford) 99:1213-1222

24. Kárpáti Z (1940) Die zwischen Sorbus aria (s.1.) und S. aucuparia stehenden Arten und Bastarde des historischen Ungarns. Index Horti Botanici 4:78-91

25. Kárpáti Z (1960) Die Sorbus-Arten Ungarns und der angrenzenden Gebiete. Feddes Repertorium 62(2-3):71-334

26. Kézdy P (1997) A hazai flóra endemikus Sorbus kisfajainak taxonómiai vonatkozásai. Kitaibelia 2(2):193-196

27. Kitchener GD (1997) A triple hybrid willowherb: Epilobium ciliatum $\times$ E. hirsutum $\times$ E. parviflorum. BSBI News 75:66-67

28. Kučerová V, Gömöry D (2011) Reticulate phylogeny in the genus Sorbus: the case of Sorbus haljamovae Bernátová et Májovský. Folia Oecologica 38(2):169-175

29. Kučerová V, Gömöry D, Duurkovič J, Paule L, Kardošová M (2011) Alloploid hybridization in the genus Sorbus: pink-flowered hybrids in the National Nature Reserve Skalná Alpa. Acta Facultatis Forestalis Zvolen 53(1):41-49

30. Leinemann L, Hosius B, Kahlert K, Kuchma O, Czernikarz H, Arenhövel W, Helmecke K (2013) Genmarkeranalysen zur Hybridbildung und natürlichen Vermehrung bei Sorbus latifolia agg. in Thüringen. Allgemeine Forst- und Jagdzeitung 184:204-213

31. Lepší M, Vít P, Lepší P, Boublík K, Suda J (2008) Sorbus milensis, a new hybridogenous species from northwestern Bohemia. Preslia 80:229-244

32. Lepší M, Lepší P, Koutecký P, Bílá J, Vít P (2015) Taxonomic revision of Sorbus subgenus Aria occurring in the Czech Republic. Preslia 87:109-162

33. Lepší M, Koutecký P, Bílá J, Lepší P, Urfus T, Rich TCG (2016) Versatility of reproductive modes and ploidy level interactions in Sorbus (Malinae, Rosaceae): playful youth and serious adults. Bot J Linn Soc 191(4):502-522

34. Levin J, Fay MF, Pellicer J, Hedrén M (2018) Multiple independent origins of intermediate species between Sorbus aucuparia and S. hybrida (Rosaceae) in the Baltic region. Nordic J Bot 25:1. https://doi.org/10.1111/njb.02035

35. Liljefors A (1934) Über normale und apospore Embryosackentwicklung in der Gattung Sorbus, nebst einigen Bemerkungen über die Chromosomenzahlen. Svensk Botanisk Tidskrift 28:290-299

36. Liljefors A (1953) Studies on propagation, embryology and pollination in Sorbus. Acta Horti Bergiani 16:277-329

37. Liljefors A (1955) Cytological studies in Sorbus. Acta Horti Bergiani 17:47-113

38. Lipnerová I, Bureš P, Horová L, Šmarda P (2013) Evolution of genome size in Carex (Cyperaceae) in relation to chromosome number and genomic base composition. Ann Bot 111:79-94

39. Maekawa M, Ha S, Kita F (1991) Identification of reciprocal translocations observed in several Melilotus species (subgenus Eumelilotus) by interspecific triple crossings. Euphytica 54:255-261

40. Mason AS, Takahira J, Atri C, Samans B, Hayward A, Cowling WA, Batley J, Nelson MN (2015) Microspore culture reveals complex meiotic behaviour in a trigenomic Brassica hybrid. BMC Plant Biol 15:173

41. Májovský J, Bernátová D (2001) New hybridogenous subgenera of the genus Sorbus L. emend. Crantz. Acta Horticulturae et Regiotecturae 4:20-21

42. Matzk F, Meister A, Schubert I (2000) An efficient screen for reproductive pathways using mature seeds of monocots and dicots. Plant J 21:97-108

43. Meikle RD, Robinson ND (2000) A new record for Salix x angusensis (Salicaceae) Rech. f. from Ainsdale Sand Dunes National Nature Reserve, S. Lancs. v.c. 59. Watsonia 23:327-330
44. Meyer N, Meierott L, Angerer O (2005) Beiträge zur Gattung Sorbus in Bayern. In: Ber. Bayer. Bot. Ges., Sonderband, pp 5-216

45. Nelson-Jones EB, Briggs D, Smith AG (2002) The origin of intermediate species of the genus Sorbus. Theor Appl Genet 105:953-963

46. Oddou-Muratorio S, Aligon C, Decroocq S, Plomion C, Lamant T, Mush-Demesure B (2001) Microsatellite primers for Sorbus torminalis and related species. Mol Ecol Notes 1:297-299

47. Otto F (1990) DAPI staining of fixed cells for high-resolution flow cytometry of nuclear DNA. In: Crissman H, Darzynkiewicz AZ (eds) Methods in cell biology 33. Academic Press, New York, pp 105-110

48. Pax F (1908) Grundzüge der Pflanzenverbreitung in den Karpathen II., Leipzig, p 321

49. Pellicer J, Clermont S, Houston L, Rich TCG, Fay MF (2012) Cytotype diversity in the Sorbus complex (Rosaceae) in Britain: sorting out the puzzle. Ann Bot 110:1185-1193

50. Pogan E, Wcisło H, Jankun A (1980) Further studies in chromosome numbers of Polish Angiosperms. Part XIII. Acta Biologica Cracoviensia Series Botanica 22:37-69

51. Popov KP (1959) A new species of whitebeams from the Crimea. Bot Mater Gerb Bot Inst Komarova Akad Nauk SSSR 19:188-196

52. Proctor MCF, Proctor ME, Groenhof AC (1989) Evidence from peroxidase polymorphism on the taxonomy and reproduction of some Sorbus populations in south-west England. New Phytol 112:569-575

53. Rich TCG (2008) Sorbus $\times$ liljeforsii, a name for the $S$. aucuparia $\times$ intermedia hybrid (Rosaceae). Nordic J Bot 25:339-341

54. Rich TCG, Houston L, Robertson A, Proctor MCF (2010) Whitebeams, rowans and service trees of Britain and Ireland. A monograph of British and Irish Sorbus L. BSBI Handbook No. 14. Botanical Society of the British Isles, London

55. Rich TCG, Green D, Houston L, Lepší M, Ludwig S, Pellicer J (2014) British Sorbus (Rosaceae): six new species, two hybrids and a new subgenus. New J Bot 4:2-12

56. Rieseberg LH, Willis JH (2007) Plant speciation. Science 317:910-914

57. Robertson A, Newton AC, Ennos RA (2004) Multiple hybrid origins, genetic diversity and population genetic structure of two endemic Sorbus taxa on the Isle of Arran, Scotland. Mol Ecol 13:123-143

58. Robertson A, Rich TCG, Allen AM, Houston L, Roberts C, Bridle JR, Harris SA, Hiscock SJ (2010) Hybridization and polyploidy as drivers of continuing evolution and speciation in Sorbus L. (Rosaceae). Mol Ecol 19:1675-1690

59. Schönswetter P, Suda J, Popp M, Weiss-Schneeweiss H, Brochmann C (2007) Circumpolar phylogeography of Juncus biglumis (Juncaceae) inferred from AFLP fingerprints, cpDNA sequences, nuclear DNA content and chromosome numbers. Mol Phylogenet Evol 42:92-103

60. Sennikov AN, Phipps JB (2013) Atlas Florae Europaeae notes, 19-22. Nomenclatural changes and taxonomic adjustments in some native and introduced species of Malinae (Rosaceae) in Europe. Willdenowia 43:33-44

61. Sennikov AN, Kurtto A (2017) A phylogenetic checklist of Sorbus s.l. (Rosaceae) in Europe. Memoranda Soc Fauna Flora Fennica 93:1-78

62. Sennikov AN (2018) Scandosorbus (Rosaceae), a new generic name for Sorbus intermedia and its hybrid. Ann Bot Fenn 55(4):321-323. https://doi.org/10.5735/085.055.0413

63. Somlyay L, Sennikov AN (2016) Atlas Florae Europaeae notes 30. Resurrection and typification of the name Sorbus semipinnata Borbás (Rosaceae). Phytotaxa 266(1):45-47

64. Talent N, Dickinson TA (2007) Endosperm formation in aposporous Crataegus (Rosaceae, Spiraeoideae, tribe Pyreae): parallels to Ranunculaceae and Poaceae. New Phytol 173:231-249 
65. Uhrinová V, Zozomová-Lihová J, Bernátová D, Paule J, Paule L, Gömöry D (2017) Origin and genetic differentiation of pinkflowered Sorbus hybrids in the Western Carpathians. Ann Bot 120(2):271-284

66. Zaikonnikova TI (1985) Renaming the Crimean species Sorbus pseudolatifolia K. Pop. (Rosaceae). Novosti Sist Vyssh Rast 22:136-138

67. Xu Q, Wen X, Deng X (2004) A simple protocol for isolating genomic DNA from Chestnut Rose (Rosa roxburghii Tratt) for RFLP and PCR analyses. Plant Mol Biol Rep 22:301

68. Zaikonnikova TI (2001) Sorbus L. In: Tzvelev NN (ed) Flora of East Europe 10. World \& Family Publishers \& St Petersburg State Chemical-Pharmaceutical Academy, St Petersburg, pp 535-543
69. Zaikonnikova TI, Kipiani VV (1980) Chromosome counts in some species of Sorbus (Rosaceae) in the flora of the USSR. Bot Žurn 65(9):1326-1330

70. Zhang P, Li W, Friebe B, Gill BS (2004) Simultaneous painting of three genomes in hexaploid wheat by BAC-FISH. Genome 47:979-987

71. Zozomová-Lihová J, Krak K, Mandáková T, Shimizu KK, Spaniel S, Vít P, Lysak MA (2014) Multiple hybridization events in Cardamine (Brassicaceae) during the last 150 years: revisiting a textbook example of neoallopolyploidy. Ann Bot 113(5):817-830 